\title{
Quercetin attenuates TNF-induced inflammation in hepatic cells by inhibiting the NF- $\mathrm{kB}$ pathway
}

Ana Belén Granado-Serrano, María Ángeles Martín, Laura Bravo, Luis

Goya and Sonia Ramos*

Department of Metabolism and Nutrition

Institute of Food Science, Technology and Nutrition-ICTAN (former Instituto del Frío)

Consejo Superior de Investigaciones Científicas (CSIC)

José Antonio Novais 10

Ciudad Universitaria, 28040, Madrid

Spain

Phone: +34.91 .544 .56 .07$

Fax: +34.91 .549 .36 .27$

* Corresponding author: e-mail: $\underline{\text { s.ramos @ictan.csic.es. }}$ 


\begin{abstract}
The dietary flavonoid quercetin is an antioxidant that possesses anti-inflammatory and anticarcinogenic properties and may modulate signaling pathways. Inflammation is considered to play a pivotal role in carcinogenesis by triggering activation of transcription factors such as $\mathrm{NF}-\kappa \mathrm{B}$, functionally dependent on cellular redox status. This study aims to investigate the anti-inflammatory effect of quercetin and its role on the NF- $\mathrm{kB}$ pathway, and COX-2 and MAPKs modulation in a human hepatoma cell line (HepG2). Quercetin alone did not modify any of the parameters analyzed but protected cells against activation of the NF- $\kappa$ B route induced by TNF- $\alpha$. This inhibitory effect of quercetin was mediated, at least in part, by ERK, JNK and reactive oxygen species, and it was accompanied by reduced COX-2 levels. These observations suggest that quercetin may contribute as an anti-inflammatory agent in the liver and provide evidences about its role in the prevention of diseases associated with inflammation, including cancer.
\end{abstract}

Keywords: COX-2, HepG2 cells, NF-кB signaling, MAPKs, Quercetin. 


\section{Introduction}

Consumption of fruits and vegetables has been connected to a reduced risk of chronic diseases, such as cancer (1), and many studies have demonstrated that one of the more active family of phytochemicals in these fruits and vegetables is that of polyphenols (1). The flavonol quercetin is the most common plant-derived flavonoid in the diet (1), and it is extensively metabolized in the small intestine and in the liver (2). Quercetin possesses antioxidant properties (3), potential anti-proliferative and anticarcinogenic activities (4-6), and it is a potent anti-inflammatory agent (7-10).

A causal relationship between inflammation and cancer has long been suspected (11). Epidemiological studies suggest that major risk factors for hepatocelullar carcinoma are persistent infection with hepatitis $\mathrm{B}$ and $\mathrm{C}$ virus and exposure to genotoxic and cytotoxic chemicals, all of which cause inflammation (12). It has been described that in this inflammatory process, the vast majority of cellular events require the nuclear factorkappa B (NF- $\mathrm{B})$ activation $(11,12)$. However, the molecular mechanisms linking chronic inflammation and cancer are not well known yet.

$\mathrm{NF}-\mathrm{\kappa B}$ is a transcription factor that regulates inflammation, immunity, apoptosis, cell proliferation and differentiation after binding to DNA and activating gene transcription $(13,14)$. NF- $\kappa \mathrm{B}$ is activated by a wide variety of inflammatory stimuli, including tumor necrosis factor $\alpha$ (TNF), interleukin-1 (IL-1), lipopolysaccharide (LPS) or $\mathrm{H}_{2} \mathrm{O}_{2}$. The cytokine TNF plays an important role in initiating and perpetuating NF- $\kappa \mathrm{B}$ signaling and chronic inflammation (15). Stimulation of cells with pro-inflammatory agents causes the activation of inhibitor of $\kappa \mathrm{B}$ (I $\kappa \mathrm{B})$ kinase (IKK), which in turn phosphorylates and degrades $\mathrm{I} \kappa \mathrm{B} \alpha$ and leads to NF- $\mathrm{B}$ translocation to the nucleus and binding to a specific DNA consensus sequence; all this results in the transcriptional 
activation of NF- $\kappa \mathrm{B}$ regulated genes involved in inflammation such as cyclooxygenase$2(\mathrm{COX}-2)(13)$.

COX-2 promoter is known to contain a NF- $\mathrm{BB}$ binding site, essential for the induction of this inflammatory enzyme that is activated in response to TNF (15). COX-2 catalyses the production of inflammatory mediators such as prostagladins and is persistently overexpressed in chronic liver inflammation and cirrhosis, as well as in experimental and human hepatocellular carcinoma $(16,17)$. COX-2 could be locally induced by proinflammatory mitogens, cytokines and growth factors during inflammation and carcinogenesis, suggesting that COX-2 may play a role in hepatocarcinogenesis (17).

In addition, the induction of NF- $\kappa \mathrm{B}$ activity by TNF can also be modulated by MAPKs, such as JNK, ERK, p38 and the PI3K/AKT pathway (15). Activation of these molecular routes depends in most cases on the production of reactive oxygen species (ROS) (18). In this regard, increased production of ROS is a common feature in both cancer and inflammation and it can stimulate the NF- $\kappa$ B pathway (18).

Recently, several studies have demonstrated that quercetin and other polyphenols suppress a number of key elements in cellular signal transduction pathways resulting in the inhibition of pro-inflammatory mediators $(7,9,10,19-21)$. Thus, quercetin and other phenolic compounds show anti-inflammatory effects through the down-regulation

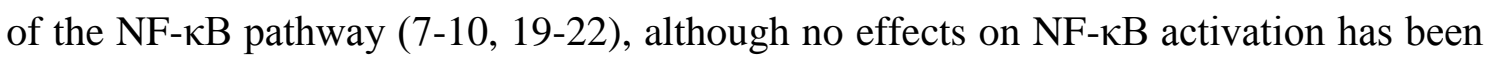
occasionally reported (23). However, the detailed molecular mechanism of action of this phenolic compound to modulate the NF- $\mathrm{BB}$ pathway and COX-2 expression in liver cells during an inflammatory process is still poorly understood.

The present study is aimed to test whether the anti-inflammatory effect of quercetin is mediated through the modulation of the NF- $\mathrm{BB}$ pathway, COX-2 and members of MAPKs family. Results demonstrate that quercetin is a potent inhibitor of the TNF- 
stimulated NF- $\kappa \mathrm{B}$ pathway, which is mediated at least in part by the inhibition of ERKand JNK-MAPKs. Quercetin also inhibits TNF-induced inflammatory enzyme COX-2 and intracellular ROS generation. 


\section{Materials and methods}

\section{Materials and chemicals}

Quercetin, 6-diamidino-2-phenylindole (DAPI), gentamicin, penicillin G and streptomycin were purchased from Sigma Chemical (Madrid, Spain). Anti-ERK1/2 and anti-phospho-ERK1/2 recognizing phosphorylated Thr202/Thy204 of ERK1/2, antiJNK1/2 and antiphospho-JNK1/2 recognizing phosphorylated Thr183/Tyr185 of JNK1/2 and anti- $\beta$-actin were obtained from Cell Signaling Technology $(9101,9102$, 9251, 9252 and 4697, respectively Izasa, Madrid, Spain). Anti-NF-кB p65 (sc-7151 and sc-372), anti-IKK $\alpha$ (sc-7218 and sc-7607), anti-IkB $\alpha$ (sc-371), anti-phospho-Ser32I $\mathrm{B} \alpha(\mathrm{sc}-21869-\mathrm{R})$, anti-PARP (sc-7150) and anti-GRB2 (sc-255) were purchased from Santa Cruz Biotechnology Inc. (Santa Cruz, CA, USA). Alexa Fluor 594 goat antirabbit $\operatorname{IgG}(\mathrm{H}+\mathrm{L})(\mathrm{A} 11012)$ and Vectashield were obtained from Molecular Probes (Invitrogen, Barcelona, Spain) and Vector Laboratories, Inc. (Atom, Barcelona, Spain), respectively. Recombinant murine TNF-alpha was from PreproTech (Tebu-bio, Madrid, Spain). Materials and chemicals for electrophoresis were from BioRad (BioRad Laboratories S.A., Madrid, Spain). Cell culture dishes and cell culture medium were from Falcon (Cajal, Madrid, Spain) and Lonza (Lonza, Madrid, Spain), respectively.

\section{Cell culture and quercetin treatment}

Human hepatoma HepG2 cells were grown in Dulbecco's Modified Eagle's Medium (DMEM) F-12 medium, supplemented with $2.5 \%$ fetal bovine serum (FBS) and antibiotics (50 mg/L gentamicin, $50 \mathrm{mg} / \mathrm{L}$ penicillin and $50 \mathrm{mg} / \mathrm{L}$ streptomycin). Cells were maintained at $37^{\circ} \mathrm{C}$ in a humidified atmosphere of $5 \% \mathrm{CO}_{2}$.

Cells were changed to serum-free medium $24 \mathrm{~h}$ before the assay in order to avoid the influence of the growth factors contained in the FBS on the results. To study the effects 
of the flavonoid, cells were treated with different concentrations of quercetin $(0.1,0.5$, $1,5$ and $10 \mu \mathrm{M})$ and then harvested at $4 \mathrm{~h}$.

To study the effects of TNF, HepG2 cells were incubated with TNF (6 ng/mL) and harvested at different times $(15,30,45$ and $60 \mathrm{~min})$. Additionally, in some cases after quercetin treatment cells were stimulated with TNF $(6 \mathrm{ng} / \mathrm{mL})$ for $30 \mathrm{~min}$.

\section{Preparation of total cell lysates}

To detect ERK1/2, phospho-ERK1/2, JNK and phospho-JNK, cells were lysed at $4^{\circ} \mathrm{C}$ in a buffer containing $25 \mathrm{mM}$ N-2-hydroxyethylpiperazine- $\mathrm{N}^{\prime}$-2-ethanesulfonic acid (HEPES) (pH 7.5), 0.3 M NaCl, $1.5 \mathrm{mM} \mathrm{MgCl}_{2}, 0.2 \mathrm{mM}$ ethylendiaminetetraacetic acid (EDTA), $\quad 0.5 \mathrm{mM}$ dithiothreitol (DTT), $0.1 \% \quad$ Triton $\quad \mathrm{X}-100,200 \mathrm{mM} \quad \beta-$ glycerolphosphate, $\quad 0.1 \quad \mathrm{mM} \quad \mathrm{Na}_{3} \mathrm{VO}_{4}, \quad 2 \mu \mathrm{g} / \mathrm{mL}$ leupeptin and $1 \mathrm{mM}$ phenylmethylsulfonyl fluoride (PMSF). The supernatants were collected, assayed for protein concentration by using the Bio-Rad (Madrid, Spain) protein assay kit according to the manufacture's specifications, aliquoted and stored at $-80^{\circ} \mathrm{C}$ until use for Western blot analyses.

\section{Preparation of nuclear and cytosolic extracts}

Cells were resuspended at $4^{\circ} \mathrm{C}$ in $10 \mathrm{mM}$ HEPES pH 7.9, $1.5 \mathrm{mM} \mathrm{MgCl}_{2}, 10 \mathrm{mM} \mathrm{KCl}$, 0.5 mM DTT, 0.2 mM PMSF (buffer A), allowed to swell on ice for $10 \mathrm{~min}$, and then vortexed for $10 \mathrm{~s}$. Samples were centrifuged at $10.000 \mathrm{~g}$ for $2 \mathrm{~min}$ and the supernatant containing the cytosolic fraction was stored at $-80^{\circ} \mathrm{C}$. The pellet was resuspended in cold buffer B (20 mM HEPES pH 7.9, 25\% glycerol, $420 \mathrm{mM} \mathrm{NaCl}, 1.5 \mathrm{mM} \mathrm{MgCl}_{2}$, $0.2 \mathrm{mM}$ EDTA, $0.5 \mathrm{mM}$ DTT, $0.2 \mathrm{mM}$ PMSF, $2.5 \mu \mathrm{g} / \mathrm{mL}$ leupeptin, $2.5 \mu \mathrm{g} / \mathrm{mL}$ aprotinin) and incubated on ice for $20 \mathrm{~min}$ for high salt extraction. Cellular debris was 
removed by centrifugation at $13.000 \mathrm{~g}$ for $10 \mathrm{~min}$ at $4{ }^{\circ} \mathrm{C}$, and the supernatant fraction containing nuclear protein extract was stored at $-80^{\circ} \mathrm{C}$. Cytosolic and nuclear proteins were measured using the protein reagent following the recommendations of the supplier, aliquoted and stored at $-80^{\circ} \mathrm{C}$ until used for Western blot and ELISA analyses.

\section{Western blot analysis}

Equal amounts of proteins $(100 \mu \mathrm{g})$ were separated by SDS-polyacrylamide gel electrophoresis and transferred to polyvinylidene difluoride (PVDF) filters (Protein Sequencing Membrane, Bio-Rad, Madrid, Spain). Membranes were probed with the corresponding primary antibody followed by incubation with peroxide-conjugated antirabbit immunoglobulin (GE Healthcare, Madrid, Spain). Blots were developed with the ECL system (GE Healthcare, Madrid, Spain). Equal loading of Western blot was ensured by $\beta$-actin and bands were quantified using a scanner and accompanying software.

\section{Measurement of the $N F-\kappa B D N A$ binding activity}

The DNA binding of NF- $\kappa B$ was measured with a colorimetric non-radioactive NF- $\kappa B$ Transcription Factor ELISA Assay (Active Motif, Rixensart, Belgium) according to the manufacturer's instructions. Briefly, nuclear extracts were incubated in the oligonucleotide-coated wells. Then, wells were washed and incubated with the antibody against NF- $\kappa \mathrm{B}$ (p65). Addition of the secondary antibody conjugated to horseradish peroxidase provided a colorimetric readout. The absorbance of each well was measured using a microplate reader at 450nm (Bio-Tek, Winooski, VT, USA).

\section{Immunofluorescence microscopy}


Immunofluorescence assay was performed as previously described (24). Briefly, HepG2 cells were seeded (25.000 cells/well) on glass coverslips with DMEM F-12 supplemented with FBS for $24 \mathrm{~h}$ and changed to serum-free medium $24 \mathrm{~h}$ before the assay. After incubation with quercetin and/or TNF for the indicated times, cells were washed with PBS at room temperature and then fixed with $3.7 \%$ paraformaldehyde for 10 min at room temperature. Cells were rinsed with PBS, permeabilized with ice-cold acetone and subsequently blocked with $1 \%$ BSA. Cells were incubated with the corresponding primary antibody and then incubated with the anti-rabbit Alexa Fluor594 conjugated secondary antibody. Nuclei were visualized by using DAPI staining. The coverslips were mounted in Vectashield and images were taken with a Zeiss Axiovert 200M immunofluorescence microscope (Carl Zeiss Microimaging GmbH, Munich, Germany) at 63x magnification. AxioVisionRel 4.6 software was used for images analysis.

\section{Cell viability assay}

Cell viability was determined using the crystal violet assay (5). HepG2 cells were seeded at low density $\left(10^{4}\right.$ cells per well) in 96-well plates, grown for $20 \mathrm{~h}$, treated with the different concentrations of quercetin for $4 \mathrm{~h}$ and/or TNF ( $6 \mathrm{ng} / \mathrm{mL}, 0-60 \mathrm{~min}$ ), and then incubated with crystal violet $(0.2 \%$ in ethanol) for $20 \mathrm{~min}$. Plates were rinsed with water, allowed to dry, and $1 \%$ sodium dodecylsulfate added. The absorbance of each well was measured using a microplate reader at $570 \mathrm{~nm}$.

\section{Cell proliferation assay (5-bromo-2'-deoxyuridine assay, BrdU)}

A colorimetric immunoassay (ELISA) was used for the quantification of cell proliferation. This method is based on the measurement of BrdU incorporation into 
genomic DNA during DNA synthesis of proliferating cells. HepG2 cells were seeded $\left(10^{4}\right.$ cells per well) in 96-well plates, grown $20 \mathrm{~h}$ and labeled by the addition of BrdU for $4 \mathrm{~h}$. Then the anti-BrdU antibody was added and the immune complexes were detected by the subsequent substrate (tetramethylbenzidine) reaction and quantified by measuring the absorbance at $620 \mathrm{~nm}$ in a microplate ELISA reader.

\section{Determination of reactive oxygen species (ROS)}

Cellular oxidative stress was quantified by the dichlorofluorescin (DCFH) assay using a microplate reader (4). Briefly, $5 \mu \mathrm{M}$ DCFH was added to the wells $\left(2 \times 10^{5}\right.$ cells per well) for $30 \mathrm{~min}$ at $37^{\circ} \mathrm{C}$. Then cells were washed twice with serum-free medium and multiwell plates were immediately measured at the fixed times in a fluorescent microplate reader (Bio-Tek, Winooski, VT) at excitation wavelength of $485 \mathrm{~nm}$ and emission wavelength of $530 \mathrm{~nm}$. After being oxidized by intracellular oxidants, DCFH becomes dichlorofluorescein (DCF) and emits fluorescence. By quantifying fluorescence, a fair estimation of the overall oxygen species generated under the different conditions was obtained.

\section{Statistics}

Prior to statistical analysis, data were tested for homogeneity of variances by the test of Levene; for multiple comparisons, one-way ANOVA was followed by the Bonferroni test when variances were homogeneous or by the Tamhane test when variances were not homogeneous. $P<0.05$ was considered significant. A SPSS version 17.0 program was used. 


\section{Results}

To establish a model for the study of the effect of quercetin on the NF- $\kappa \mathrm{B}$ pathway in HepG2 cells, we first checked the direct effect on the NF- $\kappa B$ pathway after $4 \mathrm{~h}$ treatment of cells with the flavonoid. Later, we established the time-point for further studies on the effect of quercetin on the NF- $\kappa B$ pathway to study the effect of TNF (6 $\mathrm{ng} / \mathrm{mL}$ ) stimulating NF- $\mathrm{KB}$ in HepG2 cells at different times.

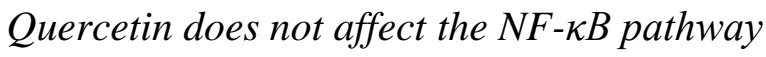

To assess whether quercetin alone affects the NF- $\kappa \mathrm{B}$ pathway, the effect of the flavonoid on $\mathrm{p}-\mathrm{I} \kappa \mathrm{B}, \mathrm{I} \kappa \mathrm{B}, \mathrm{IKK}$ and NF- $\mathrm{BB}$ protein levels were evaluated after $4 \mathrm{~h}$ of incubation with different concentrations of the polyphenol. As shown in Figures 1A and 1B, quercetin did not modify any of the mentioned protein levels and it did not affect the translocation of $\mathrm{NF}-\mathrm{\kappa B}$, as the nuclear and cytosolic levels of this transcription factor remain unchanged after the flavonoid incubation. Additionally, it should be mentioned that no cytotoxicity and no effect on cell proliferation were observed in quercetin-treated cells at $24 \mathrm{~h}$ with any of the flavonoid concentrations tested (data not shown).

\section{TNF induces $N F-\kappa B$ and IKK activation}

TNF is one of the most potent activators of NF- $\kappa \mathrm{B}$, but the mechanism of activation of NF- $\mathrm{BB}$ is not fully established. Thus, the effect of TNF $(6 \mathrm{ng} / \mathrm{mL})$ through time to

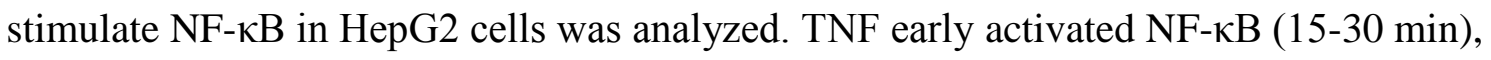
as shown by the remarkable enhancement in the relative amount of nuclear versus cytosolic NF-кB levels, followed by a decrease to control levels at 60 min (Figures 2A- 
2C). Therefore, $30 \mathrm{~min}$ time, which showed the highest activation of NF-kB was selected as standard treatment to activate NF- $\kappa \mathrm{B}$ in HepG2 cells.

Since TNF induces NF- $\kappa B$ activation, the regulation of upstream members of the NF- $\kappa B$ signaling pathway was next investigated. Similar to the activation profile of NF- $\mathrm{B}$, TNF induced an increase in the nuclear/cytosolic IKK ratio, which was maximum after 30 min of incubation, later recovering control levels (60 min) (Figures 2A and 2B).

The concentration of TNF used and the time of exposure had no effect on the viability of the cells (data not shown).

\section{Quercetin inhibits TNF-induced NF- $\kappa B$ and IKK activation}

The effect of quercetin on TNF-induced NF- $\kappa B$ activation was studied in HepG2 cells preincubated for $4 \mathrm{~h}$ with different concentrations of quercetin and then treated with TNF (6 ng/mL) for $30 \mathrm{~min}$. Results in Figures $3 \mathrm{~A}$ and $3 \mathrm{~B}$ shows that the flavonoid abolished the TNF-dependent activation of NF- $\kappa \mathrm{B}$.

To further confirm the effect of quercetin pretreatment on the suppression of nuclear translocation of NF- $\kappa \mathrm{B}$, an immunocytochemistry assay was performed. As shown in Figure 3C, after 30 min of incubation TNF clearly induced nuclear translocation of p65$\mathrm{NF}-\kappa \mathrm{B}$, whereas pretreatment with quercetin suppressed its translocation to the nucleus, in agreement with the Western blot results (Figures 3A and 3B).

Correspondingly to NF- $\kappa \mathrm{B}$, quercetin incubation suppressed the TNF-induced IKK levels, resulting in the inhibition of IKK translocation in a concentration-dependent manner (Figures 3A and 3B).

The concentration of quercetin and TNF used and the time of exposure had no effect on the viability of the cells (data not shown). 
Quercetin inhibits NF- $\kappa B$ DNA binding activity

To determine whether quercetin blocks NF- $\kappa \mathrm{B}$ activation by interfering with its binding to DNA, nuclear extracts were prepared from quercetin-pretreated cells, incubated with $6 \mathrm{ng} / \mathrm{mL}$ TNF for $30 \mathrm{~min}$ and then examined for their ability to bind to DNA. Figure 3D shows that TNF treatment highly increased the binding of NF- $\kappa$ B to the DNA, and that quercetin pretreatment caused a dose-dependent reduction on DNA binding of this transcription factor.

\section{Quercetin inhibits TNF-dependent I $\mathrm{KB}$ phosphorylation}

I $\mathrm{B}$ is phosphorylated by IKK (13), and we have demonstrated that quercetin diminished TNF-induced IKK levels in a dose-dependent manner, then the effect of quercetin pretreatment and later incubation with TNF $(6 \mathrm{ng} / \mathrm{mL})$ on $\mathrm{I} \kappa \mathrm{B}$ phosphorylation was determined. TNF induced I $\kappa$ B phosphorylation, showed maximum levels after $30 \mathrm{~min}$ of incubation, followed by a decrease to values comparable to untreated cells at 45 and 60 min (Figures 4A and 4B).

Quercetin pretreatment suppressed the TNF-induced IкB phosphorylation, recovering control values after $10 \mu \mathrm{M}$ quercetin incubation (Figures 4C and 4D).

\section{Quercetin inhibits TNF-dependent IкB degradation}

Translocation of NF- $\mathrm{BB}$ to the nucleus is preceded by the proteolytic degradation of $\mathrm{I} \kappa \mathrm{B}$ (13). Thus, TNF incubation caused a rapid reduction of IאB levels (15-30 min) to later return to control levels after 45 min of treatment onwards (Figures $4 \mathrm{~A}$ and $4 \mathrm{~B}$ ).

To determine whether quercetin inhibition of TNF-induced NF- $\kappa \mathrm{B}$ activation was due to inhibition of I $\mathrm{B}$ degradation, cells were pretreated with the flavonoid for $4 \mathrm{~h}$, then exposed to TNF for $30 \mathrm{~min}$ and $\mathrm{I} \kappa \mathrm{B}$ levels analyzed. Quercetin induced a restoration in 
$\mathrm{I} \kappa \mathrm{B}$ levels, although $\mathrm{I} \kappa \mathrm{B}$ control values were not totally reached even with the highest concentration of quercetin $(10 \mu \mathrm{M})$ (Figures $4 \mathrm{C}$ and $4 \mathrm{D})$.

\section{Quercetin attenuates ROS overproduction induced by TNF}

$\mathrm{NF}-\mathrm{kB}$ activation is also related to ROS production (18). Accordingly, HepG2 cells were treated with different quercetin concentrations for $4 \mathrm{~h}$ and then exposed to TNF (6 $\mathrm{ng} / \mathrm{mL}$ ) for $30 \mathrm{~min}$. As shown in Figure 5, cells incubated with TNF showed an increased ROS production, whereas DCF fluorescence intensity significantly dropped in the presence of $0.5-10 \mu \mathrm{M}$ quercetin, reaching values even lower that those of untreated control cells.

\section{Quercetin represses $T N F$-induced COX-2 levels}

A number of studies have demonstrated that quercetin and other polyphenols show antiinflammatory effects through downregulation of $\operatorname{COX}-2(7,22)$. It is also known that this inducible enzyme contributes to the pathogenesis of various inflammatory diseases and tumor growth $(16,17)$. Therefore, it was considered relevant to assess whether quercetin alone affects COX-2 protein and the effect of the flavonoid on its levels was evaluated after $4 \mathrm{~h}$ of incubation with different concentrations of the polyphenol. As shown in Figures $6 \mathrm{~A}$ and $6 \mathrm{~B}, 5-10 \mu \mathrm{M}$ quercetin diminished COX-2 protein levels.

COX-2 is activated in response to TNF by NF- $\kappa \mathrm{B}$ (15). Thus, it was investigated whether quercetin pretreatment can suppress COX-2 protein levels. As shown in Figures $6 \mathrm{C}$ and 6D, TNF induced COX-2 values in HepG2 cells and quercetin pretreatment partly suppressed them, showing comparable values to untreated cells with $10 \mu \mathrm{M}$ quercetin. 


\section{Quercetin inhibits TNF-induced activation of JNK and ERK}

ERK-MAPK and JNK-MAPK play an important role in cell survival/proliferation as well as in apoptosis, and can be modulated by polyphenols (1). To investigate whether quercetin treatment in HepG2 cells was able to activate key proteins related to cellular survival/proliferation or apoptosis, ERK and JNK were analyzed. Figures 7A and 7B illustrate that a $4 \mathrm{~h}$ treatment with quercetin did not show a significant effect on the levels phosphorylated ERK and JNK in HepG2 cells. Likewise, there was no difference in the total levels of ERK and JNK. These results, together with the lack of effect on cell damage and on cell proliferation reported above, suggest that $4 \mathrm{~h}$ of treatment with quercetin has neither a prominent cytotoxic effect nor a proliferative/survival action in HepG2 cells.

TNF is a potent activator of JNK and ERK, which have been implicated in the activation of NF-кB (25). Therefore, the effect of quercetin on TNF-induced activation of these MAPKs was investigated. HepG2 cells were pretreated for $4 \mathrm{~h}$ with quercetin and then stimulated with TNF $(6 \mathrm{ng} / \mathrm{mL})$ for $30 \mathrm{~min}$.

TNF activated JNK phosphorylation by about 7 fold, an activation that was gradually reverted with increasing concentrations of quercetin. Quercetin $(10 \mu \mathrm{M})$ completely inhibited the enhancement in the p-JNK levels induced by TNF (Figures 7C and 7D). Quercetin also inhibited the TNF-induced activation of ERK in a dose-dependent manner to reach control values at 5 and $10 \mu \mathrm{M}$ quercetin (Figures $7 \mathrm{C}$ and 7D). Total ERK and JNK protein levels did not change during Q plus TNF exposure. 


\section{Discussion}

Quercetin is commonly consumed in the diet and a large body of evidence indicates that it possesses a variety of biological activities including antioxidant (3), antiproliferative (4-6), and anti-inflammatory $(7,10)$. The apoptotic and anti-inflammatory effects of quercetin and the gene expression pattern associated to these processes could suggest that quercetin likely suppresses NF- $\mathrm{BB}$ activation. However no studies have been conducted on the cellular mechanisms involved in the quercetin-mediated regulation of pro-inflammatory mediators in TNF-stimulated hepatic cells.

In this study a model of inflammation in $\mathrm{HepG} 2$ cells for NF- $\kappa \mathrm{B}$ activation induced by TNF has been established and the effect of quercetin on NF-kB pathway, ROS production, MAPKs (ERK and JNK) and COX-2 modulation has been tested. Here evidence is provided for the potential role of quercetin in reducing TNF-induced inflammation through downregulation of NF-кB, ERK, JNK, COX-2 and ROS generation.

Inappropriate modulation of $\mathrm{NF}-\mathrm{kB}$, which is a major molecular coordinator of inflammatory responses (11-14), has been associated with various pathological conditions including cancer, and constitutes one of the key pathways affecting the development of many chronic diseases (12-14). We have found that TNF rapidly causes phosphorylation and degradation of I $\mathrm{KB}$, as well as IKK and NF- $\mathrm{B}$ activation, in agreement with previous studies (15), whereas quercetin alone, at the doses used in this work, does not affect the NF- $\mathrm{BB}$ pathway. However, studies concerning the relationship between flavonoids and the NF- $\mathrm{BB}$ pathway are discrepant. Thus, it has been reported that dietary quercetin does not reduce NF- $\mathrm{B}$ activation in the renal cortex of rats with established chronic glomerular disease (23) and that quercetin does not suppress DNA binding activation of NF- $\mathrm{BB}$ in LPS-stimulated macrophages (26). It has also been 
described that quercetin fails to inhibit TNF- $\alpha$-induced NF- $\kappa \mathrm{B}$ translocation in osteoblasts (27), and that apple, cherry and blackcurrant (containing quercetin)

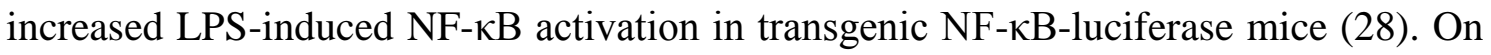
the contrary, our results demonstrate that quercetin is a potent inhibitor of NF- $\kappa \mathrm{B}$ activation induced by the pro-inflammatory agent TNF. Thus, in TNF-stimulated HepG2 cells quercetin decreased I $\mathrm{B} \alpha$ degradation and repressed upregulation of IKK, and these effects on the $\mathrm{IKK} / \mathrm{I} \kappa \mathrm{B}$ cascade would in turn contribute to the inhibition of the NF- $\kappa \mathrm{B}$ activation. This is in agreement with reports showing that quercetin prevents LPS-IкB phosphorylation in bone marrow derived macrophages (29), that quercetin inhibits NF-кB activation induced by different pro-inflammatory agents, including TNF, in hepatic $(9,19)$, and epithelial cells $(10)$, as well as in macrophages (8). Similarly, quercetin reduces polyp number and size distribution in the $\mathrm{Apc}^{\mathrm{Min} /+}$ mouse by reducing inflammation, as diminished macrophage infiltration (30). Quercetin also significantly decreases the phosphorylation of $\mathrm{I} \kappa \mathrm{B} \alpha / \beta$ in $\mathrm{TNF}$-stimulated peripheral blood mononuclear cells (31).

Many reports have demonstrated the cytotoxicity of quercetin as a pro-apoptotic agent (4-6). To exclude the possibility that quercetin may affect the viability and/or proliferation of hepatic cells, the toxicity of the flavonoid after $24 \mathrm{~h}$ treatment was investigated. In full agreement with previous results, quercetin was not toxic to human HepG2 cells at concentrations $\leq 10 \mu \mathrm{M}(4,19,32)$. Similarly, cell viability was neither affected by 30 min-TNF incubation alone or in combination with the flavonoid.

ROS are proposed to be involved in NF- $\kappa \mathrm{B}$ activation (18). Likewise, many antioxidants exert an inhibitory action on NF- $\mathrm{BB}$ activation through the modulation of the intracellular redox status $(9,33)$. In line with this, TNF-induced ROS generation could be related to the stimulation of the NF- $\kappa B$ pathway (18), whereas inhibition of the 
$\mathrm{NF}-\kappa \mathrm{B}$ signaling could be associated, at least partly, to the significant free radical scavenger properties of quercetin. Similarly, quercetin attenuates the NF- $\mathrm{B}$ activation induced by IL-1, which in turn stimulates ROS production (9). Thus, these results suggest the importance of intracellular ROS levels for quercetin-inhibited NF- $\kappa \mathrm{B}$ activation in HepG2 cells.

Regulation of COX-2 is a complex process and its pathways of induction seem to converge in the activation of NF- $\kappa \mathrm{B}$. Moreover, COX-2 is regulated by NF- $\kappa \mathrm{B}$ and both proteins are involved in tumor promotion and inflammation $(13,17,34)$. COX-2 is rarely expressed constitutively, but it is highly induced by cytokines, growth factors and tumor promoters (17). The present results indicate that TNF induces COX-2 protein in HepG2 cells, which could be related to the activation of the NF- $\kappa$ B pathway (34), whereas quercetin effectively reduced COX-2 protein levels in HepG2 cells stimulated with TNF. In concert, it has been reported a decreased COX-2 expression in human endothelial cells stimulated with a mixture of cytokines (containing TNF) previously treated with quercetin (35). Quercetin alone also diminished COX-2 levels and downregulated the NF-אB pathway in liver cells (7). Similarly, the flavonoid resveratrol inhibited the overexpression of COX-2 and the nuclear translocation of $\mathrm{NF}-\kappa \mathrm{B}$ in hepatocytes during rat hepatocarcinogenesis initiated with diethylnitrosamine (16). Therefore, it is possible that blockade of the NF- $\kappa \mathrm{B}$ activation by quercetin contributes to the downregulation of COX-2 expression. Thus, the preventive effect of quercetin against TNF-induced changes in HepG2 cells may be due to the ability of the flavonoid to modulate different molecular signals and to inhibit intracellular ROS generation.

Phosphorylation plays an important role in activating protein tyrosine kinases. Since accumulating evidence involves ERK and JNK pathways in NF- $\kappa \mathrm{B}$ activation (34) in the current study, we examined the effect of quercetin on ERK- and JNK-MAPKs in the 
absence and presence of TNF. Quercetin did not show a significant effect on the levels of p-JNK or p-ERK, but it inhibited ERK and JNK activation dose-dependently in TNFactivated HepG2 cells, similarly to what has been shown for quercetin and other natural compounds in different cell lines stimulated with IL-1, LPS or TNF $(36,37)$. These results suggest that the inhibition of ERK and JNK, at least in part, are required for the inhibitory effect of quercetin on the TNF-induced upregulation of NF- $\kappa B$. In this line, Chen et al (38) reported that vanadate treatment activated NF- $\kappa \mathrm{B}$ through JNK activation in macrophages. Similarly, other studies showed that the specific inhibitor of ERK pathway blocked the nuclear activity of NF- $\mathrm{BB}$ (39). However, the participation of other signaling pathway in the modulation of the NF- $\kappa \mathrm{B}$ activity cannot be ruled out $(34,39)$.

It is noteworthy that the concentrations of quercetin used in the present study are not far from realistic. In human subjects, plasma concentrations in the micromolar range (0.3$0.75 \mu \mathrm{M})$ have been reported after consumption of $80-100 \mathrm{mg}$ quercetin equivalent administered in the form of apples, onions, or meals rich in plant products (40). Plasma concentrations reached $1.5 \mu \mathrm{M}$ after 28 days of supplementation with $>1 \mathrm{~g}$ /day of quercetin (41). Moreover, levels of 10-50 $\mu \mathrm{M}$ quercetin have been observed after ingestion of 1-2 $\mathrm{g}$ of quercetin (40).

In summary, the present study demonstrates that quercetin inhibits TNF-induced COX-2 and NF- $\mathrm{BB}$ pathway, which suggests that this flavonoid may act as an anti-inflammatory agent in the liver. The inhibitory effect of quercetin on the TNF-induced NF- $\kappa \mathrm{B}$ activation is mediated, at least in part, by modulation of ROS generation, ERK and JNK. 


\section{Abbreviations used}

COX-2, cyclooxygenase-2; DAPI, 6-diamidino-2-phenylindole; DMEM, Dulbecco's Modified Eagle's Medium; DTT, dithiothreitol; EDTA, ethylendiaminetetraacetic acid; ERK, extracellular regulated kinase; FBS, fetal bovine serum; GRB2, growth factor receptor-bound protein 2; HEPES, N-2-hydroxyethylpiperazine-N'-2-ethanesulfonic acid; HUVEC, human umbilical vein endothelial cells; IкB $\alpha$, inhibitor kappa B protein $\alpha$; IKK, IкB $\alpha$ kinase; IL-1, interleukin-1; JNK, $c$-jun amino-terminal kinase; LPS, lipopolysaccharide; MAPK, mitogen-activated protein kinase; NF- $\kappa \mathrm{B}$, nuclear factor kappa B; PARP, poly (ADPribose) polymerase; PMSF, phenylmethylsulfonyl fluoride; SDS, sodium dodecylsulfate; TNF, tumor necrosis factor.

\section{Acknowledgements}

This work was supported by the grants 200870 I198 (CSIC) and CSD2007-00063 from the Spanish Ministry of Science and Innovation (CICYT). A.B. Granado-Serrano was a predoctoral fellow of the Spanish Ministry of Science and Education. 


\section{References}

1. Ramos S: Cancer chemoprevention and chemotherapy: dietary polyphenols and signalling pathways. Mol Nutr Food Res 52, 507-526, 2008.

2. Spencer J, Chowrimootoo G, Choudhury R, Debnam E, Srai S, et al.: The small intestine can both absorb and glucuronidate luminal flavonoids. FEBS Lett 458, 224230, 1999.

3. Alía M, Ramos S, Mateos R, Granado-Serrano A, Bravo L, et al.: Quercetin protects human hepatoma cell line (HepG2) against oxidative stress induced by tertbutyl hydroperoxide. Toxicol Appl Pharmacol 212, 110-118, 2006.

4. Granado-Serrano A, Martín M, Bravo L, Goya L and Ramos S: Quercetin induces apoptosis via caspase activation, regulation of Bcl-2, and inhibition of PI-3Kinase/Akt and ERK pathways in a human hepatoma cell line (HepG2). J Nutr 136, 2715-2721, 2006.

5. Granado-Serrano A, Martin M, Bravo L, Goya L and Ramos S: Time-course regulation of quercetin on cell survival/proliferation pathways in human hepatoma cells. Mol Nutr Food Res 52, 457-464, 2008.

6. Granado-Serrano A, Martin M, Bravo L, Goya L and Ramos S: Quercetin modulates NF- $\kappa \mathrm{B}$ and AP-1/JNK pathways to induce cell death in human hepatoma cells. Nutr \& Cancer 62, 390-401, 2010.

7. Garcia-Mediavilla V, Crespo I, Collado P, Esteller A, Sanchez-Campos S, et al.: The anti-inflammatory flavones quercetin and kaempferol cause inhibition of inducible nitric oxide synthase, cyclooxygenase- 2 and relative C-protein, and down-regulation of the nuclear factor-kappaB pathway in Chang liver cells. Eur J Pharmacol 557, 221-229, 2007. 
8. Hämäläinen $\mathrm{M}$, Nieminen R, Vuorela $\mathrm{P}$, Heinonen $\mathrm{M}$ and Moilanen E: Antiinflammatory effects of flavonoids: genistein, kaempferol, quercetin, and daidzein inhibit STAT-1 and NF-kB activations, whereas flavone, isorhamnetin, naringenin, and pelargonidin inhibit only NF-kB activation along with their inhibitory effect on iNOS expression and NO production in activated macrophages. Mediators Inflammation Article ID 45673, doi:10.1155/2007/45673, 2007.

9. Martinez-Florez S, Gutierrez-Fernandez B, Sanchez-Campos S, GonzalezGallego J and Tuñon M: Quercetin attenuates nuclear factor-kB activation and nitric oxide production in interleukin-1b-activated rat hepatocyte. J Nutr 135, 1359-1365, 2005.

10. Ruiz PA, Braune A, Hölzlwimmer G, Quintanilla-Fend L and Haller D: Quercetin inhibits TNF-induced NF-kB transcription factor recruitment to proinflammatory gene promoters in murine intestinal epithelial cells. J Nutr 137, 12081215, 2007.

11. Pan M-H, Lai C-S and Ho C-T: Anti-inflammatory activity of natural dietary flavonoids. Food Funct doi: 10.1039/c0fo00103a, 2010.

12. Muriel P: NF-kB in liver diseases: a target for drug therapy. J Appl Toxicol 29, 91-100, 2009.

13. Naugler W and Karin M: NF-kB and cancer-identifying targets and mechanisms. Curr Opin Gen Dev 18, 1-8, 2008.

14. Guo W, Kong EH and Meydani M: Dietary polypheols, inflammation and cancer. Nutr \& Cancer 61, 807-810, 2009.

15. Balkwill F: TNF-alpha in promotion and progression of cancer. Cancer Metastasis Rev 25, 409-416, 2006. 
16. Bishayee A, Waghray A, Barnes KF, Mbimba T, Bhatia D, et al.: Suppression of the inflammatory cascade is implicated in resveratrol chemoprevention of experimental hepatocarcinogenesis. Pharm Res 27, 1080-1091, 2010.

17. Wu T: Cyclooxygenase-2 in hepatocellular carcinoma. Cancer Treat Rev 32, 2844, 2006.

18. Gloire G, Legrand-Poels $\mathrm{S}$ and Piette $\mathrm{J}$ : NF-kB activation by reactive oxygen species: fifteen years later. Biochem Pharmacol 72, 1493-1505, 2006.

19. Musonda C and Chipman J: Quercetin inhibits hydrogen peroxide (H2O2)induced NF-kB DNA binding activity and DNA damage in HepG2 cells. Carcinogenesis 19, 1583-1589, 1998.

20. Ramiro E, Franch A, Castellote C, Pérez-Cano F, Permanyer J, et al.: Flavonoids from Theobroma cacao down-regulate inflammatory mediators. J Agric Food Chem 53, 8506-8511, 2005.

21. Zafra-Stone S, Yasmin T, Bagchi M, Chatterjee A, Vinson JA, et al.: Berry anthocyanins as novel antioxidants in human health and disease prevention. Mol Nutr Food Res 51, 675-683, 2007.

22. Umesalma S and Sudhandiran G: Differential inhibitory effects of the polyphenol ellagic acid on inflammatory mediators NF-kB, iNOS, COX-2, TNF-alpha, and IL-6 in 1,2-dimethylhydrazine-induced rat colon carcinogenesis. Basic Clin Pharmacol Toxicol 107, 650-655, 2010.

23. Rangan GK, Wang Y and Harris DC: Dietary quercetin augments activator protein-1 and does not reduce nuclear factor-kappa B in the renal cortex of rats with established chronic glomerular disease. Nephron 90, 313-319, 2002.

24. Granado-Serrano A, Marin MA, Haegeman G, Goya L, Bravo L, et al.: Epicatechin induces NF-kB, activator protein-1 (AP-1) and nuclear transcription factor 
erythroid 2p45-related factor-2 (Nrf2) via phosphatidylinositol-3-kinase/protein kinase $\mathrm{B}(\mathrm{PI} 3 \mathrm{~K} / \mathrm{AKT})$ and extracellular regulated kinase (ERK) signalling in HepG2 cells. Brit J Nutr 103, 168-179, 2010.

25. Sethi G, Sung B and Aggarwal B: Nuclear factor-kB activation: from bench to bedside. Exp Biol Med 233, 21-31, 2008.

26. Kim BH, Cho SM, Reddy AM, Kim YS, Min KR, et al.: Down-regulatory effect of quercitrin gallate on nuclear factor- $\kappa \mathrm{B}$-dependent inducible nitric oxide synthase expression in lipopolysaccharide-stimulated macrophages RAW 264.7. Biochem. Pharmacol 69, 1577-1583, 2005.

27. Pang JL, Ricupero DA, Huang S, Fatma N, Sing DP, et al.: Differential activity of kaempferol and quercetin in attenuating tumor necrosis factor receptor family signaling in bone cells. Biochem. Pharmacol 71, 818-826, 2006.

28. Balstad TR, Paur I, Poulsen M, Markowski J, Kolodziejczyk K, et al.: Apple, cherry, and blackcurrant increases nuclear factor kappa B activation in liver of transgenic mice. Nutr \& Cancer 62, 841-848, 2010.

29. Comalada M, Camuesco D, Sierra S, Ballester I, Xaus J, et al.: In vivo quercitrin anti-inflammatory effect involves releases of quercetin, which inhibits inflammation through down-regulation of NF-kappaB pathway. Eur J Immunol 35, 584-592, 2005.

30. Murphy A, Davis JM, McClellan JL and Carmichael MD: Quercetin's effects on intestinal polyp multiplicity and macrophage number in the $\mathrm{Apc}^{\mathrm{Min} /+}$ mouse. Nutr \& Cancer 63, 421-426, 2011.

31. Nair MP, Mahajan S, Reynolds JL, Aalinkeel R, Nair H, et al.: The flavonoid quercetin inhibits proinflammatory cytokine (Tumor necrosis factor alpha) gene expression in normal peripheral mononuclear cells via modulation of the NF- $\kappa B$ system. Clin Vaccine Immunol 13, 319-328, 2006. 
32. Alia M, Mateos R, Ramos S, Lecumberri E, Bravo L, et al.: Influence of quercetin and rutin on growth and antioxidant defense system of a human hepatoma cell line (HepG2). Eur J Nutr 45, 19-28, 2006.

33. Trombetta D, Cimino F, Cristiani MT, Mandalari G, Saija A, et al.: In vitro protective effects of two extracts from bergamot peels on human endothelial cells exposed to tumor necrosis factor-alpha (TNF-alpha). J Agric Food Chem 58, 84308436, 2010.

34. Chun K-S and Surh Y-J: Signal transduction pathways regulating cyclooxygenase-2 expression: potential molecular targets for chemoprevention. Biochem Pharmacol 68, 1089-1100, 2004.

35. Crespo I, García-Mediavilla V, Gutierrez B, Sanchez-Campos S, Tuñon MJ, et al.: A comparison of the effects of kaempferol and quercetin on cytokine-induced proinflammatory status of cultured human endothelial cells. Br J Nutr 100, 968-976, 2008.

36. Lai C-S, Lee J-H, Ho C-T, Liu CB, Wang J-M, et al.: Rosmanol potently inhibits lipopolysaccharide-induced iNOS and COX-2 exppression through dowregulating MAPK, NF-kB, STAT3 and C/EBP signaling pathways. J Agric Food Chem 57, 1099010998, 2009.

37. Ying B, Yang T, Song X, Hu X, Fan H, et al.: Quercetin inhibits IL-1 betainduced ICAM-1 expression in pulmonary epithelial cell line A459 through MAPK pathway. Mol Biol Rep 36, 1825-1832, 2009.

38. Chen F, Demers LM, Vallyathan V, Ding M, Lu Y, et al.: Vanadate induction of NF-kappaB involves IkappaB kinase beta and SAPK/ERK kinase 1 in macrophages. $J$ Biol Chem 274, 20307-20312, 1999.

39. Vanden Berghe W, Plaisance S, Boone E, De Boscher K, Schmitz ML, et al.: p38 and extrcellular signal-regulated kinase mitogen-activated protein kinase pathways 
are required for nuclear factor-kappaB p65 transactivation mediated by tumor necrosis factor. J Biol Chem 273, 3285-3290, 1998.

40. Granado-Serrano $\mathrm{AB}$ and Ramos S: Molecular targets of quercetin in cancer chemoprevention. CAB Reviews: Perspectives in Agriculture, Veterinary Science, Nutrition and Natural Resources 5, 35 (doi: 10.1079/PAVSNNR20105035), 2010.

41. Manach C, Williamson G, Morand C, Scalbert A and Rémésy C: Bioavailability and bioefficacy of polyphenols in humans. I. Review of 97 bioavailability studies. Am J Clin Nutr 81(suppl), 230S-242S, 2005. 


\section{Figure captions}

Figure 1. Effect of quercetin on phosphorylated $\mathrm{I} \kappa \mathrm{B} \alpha(\operatorname{Ser} 32)$, total $\mathrm{I} \kappa \mathrm{B} \alpha$, IKK and (p65) NF- $\mathrm{B}$ levels. (A) Bands of a representative experiment (means $\pm \mathrm{SD}, \mathrm{n}=5-8$ ). Equal loading of Western blots was ensured by $\beta$-actin. Means without a common letter differ, $P<0.05$. (B) Immunofluorescence images of dose-dependent status and cellular localization of NF- $\kappa \mathrm{B}$ (p65). 6-Diamidino-2-phenylindole (DAPI) staining was used to visualize nuclei. These results are representative of two independent experiments.

Figure 2. Effect of TNF on cytosolic (C) and nuclear (N) (p65) NF- $\kappa B$ and IKK levels. (A) Bands of a representative experiment. Anti-growth factor receptor-bound protein-2 (GRB2) and anti-poly (ADPribose) polymerase (anti-PARP) antibodies were used as markers for the cytosolic and nuclear extracts, respectively. (B) Nuclear/cytosolic (Nuc/cyt) NF-אB and nuc/cyt IKK ratios of bands determined by densitometric quantification. Values are means $(n=6-7)$, with standard deviations represented by vertical bars. Mean values with different letters were significantly different $(P<0.05)$. (C) Immunofluorescence images of time-dependent status and cellular localization of NF- $\kappa$ B (p65). 6-Diamidino-2-phenylindole (DAPI) staining was used to visualize nuclei. These results are representative of two independent experiments.

Figure 3. Effect of quercetin pretreatment on cytosolic $(\mathrm{C})$ and nuclear $(\mathrm{N})(\mathrm{p} 65) \mathrm{NF}-$ $\kappa \mathrm{B}$ and IKK levels in TNF-stimulated cells. (A) Bands of a representative experiment. Anti-growth factor receptor-bound protein-2 (GRB2) and anti-poly (ADPribose) polymerase (anti-PARP) antibodies were used as markers for the cytosolic and nuclear

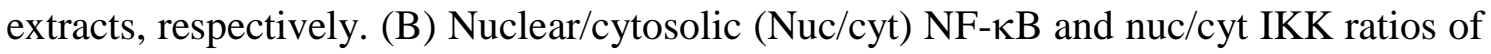


bands determined by densitometric quantification (means $\pm \mathrm{SD}, \mathrm{n}=6-8$ ). Means without a common letter differ, $P<0.05$. (C) Immunofluorescence images of dose-dependent status and cellular localization of NF- $\mathrm{BB}$ (p65). 6-Diamidino-2-phenylindole (DAPI) staining was used to visualize nuclei. These results are representative of two independent experiments. (D) DNA-binding activity of $\mathrm{NF}-\kappa \mathrm{B}$ (p65) (means $\pm \mathrm{SD}, \mathrm{n}=$ 8). Absorbance was measured at $450 \mathrm{~nm}$. Means without a common letter differ, $P<0.05$.

Figure 4. (A) Time-course effect of TNF on phosphorylated $\mathrm{I} \kappa \mathrm{B} \alpha(\mathrm{Ser} 32)$ and total $\mathrm{I} \kappa \mathrm{B} \alpha$ levels. Bands of a representative experiment. (B) Percentage values of $\mathrm{p}-\mathrm{I} \kappa \mathrm{B} \alpha$ and total $\mathrm{I} \kappa \mathrm{B} \alpha$ relative to the control condition after TNF treatment (means $\pm \mathrm{SD}, \mathrm{n}=7-9$ ). (C) Effect of quercetin pretreatment on $\mathrm{p}-\mathrm{I} \kappa \mathrm{B} \alpha$ and total $\mathrm{I} \kappa \mathrm{B} \alpha$ levels in TNF-stimulated cells. Representative blots. (D) Percentage data of $\mathrm{p}-\mathrm{I} \kappa \mathrm{B} \alpha$ and total $\mathrm{I} \kappa \mathrm{B} \alpha$ relative to the control condition (means $\pm \mathrm{SD}, \mathrm{n}=6-8$ ) in quercetin pretreated cells and later stimulated with TNF (30 min). Equal loading of Western blots was ensured by $\beta$-actin. Means without a common letter differ, $P<0.05$.

Figure 5. Effect of pretreatment with quercetin on intracellular ROS generation induced by TNF. HepG2 cultures were treated with the noted concentrations of quercetin for $4 \mathrm{~h}$, then the cultures were washed twice and TNF $(6 \mathrm{ng} / \mathrm{mL})$ was added to all cells except controls for $30 \mathrm{~min}$, and intracellular ROS production was evaluated and expressed as fluorescence units. Values are means \pm SD of 10-12 different samples per condition. Different letters denote statistically significant differences $(P<0.05)$. 
Figure 6. (A) Effect of quercetin on COX-2 levels. Bands of a representative experiment. (B) Percentage values of COX-2 relative to the control condition (means \pm $\mathrm{SD}, \mathrm{n}=6-8)$ after quercetin treatment for $4 \mathrm{~h}$. (C) Effect of quercetin pretreatment on COX-2 levels in TNF-stimulated cells. Representative blots. (D) Percentage data of COX-2 relative to the control condition (means $\pm \mathrm{SD}, \mathrm{n}=7-8$ ) in quercetin pretreated cells and later stimulated with TNF (30 min). Equal loading of Western blots was ensured by $\beta$-actin. Means without a common letter differ, $P<0.05$.

Figure 7. (A) Effect of quercetin on phosphorylated and total JNK, phosphorylated and total ERK1/2 levels. Bands of a representative experiment. (B) Percentage data of pJNK/JNK and p-ERK/ERK ratios relative to controls (means $\pm \mathrm{SD}, \mathrm{n}=6-8$ ) after quercetin treatment for $4 \mathrm{~h}$. (C) Effects of quercetin pretreatment on phosphorylated and total JNK, phosphorylated and total ERK1/2. Cells were incubated with different concentrations of quercetin for $4 \mathrm{~h}$ followed by TNF exposure. Representative blots of the above proteins. (D) Percentage data $\mathrm{p}-\mathrm{JNK} / \mathrm{JNK}$ and $\mathrm{p}$-ERK/ERK ratios relative to controls (means $\pm \mathrm{SD}, \mathrm{n}=5-8$ ). The same blots were re-probed with $\beta$-actin. Means without a common letter differ, $P<0.05$. 
Figure 1

A

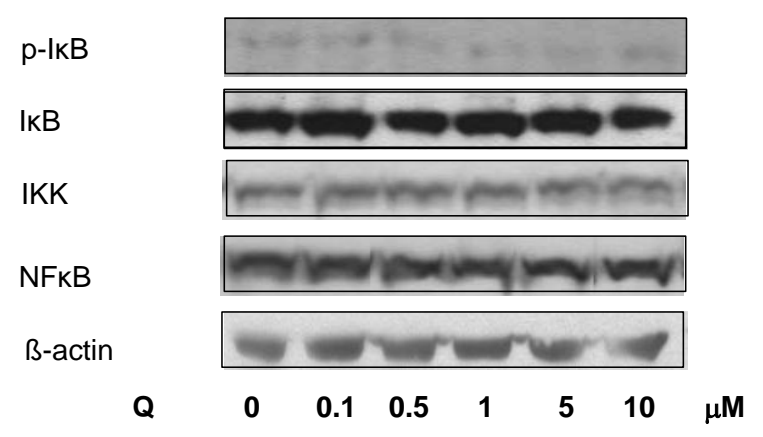

B
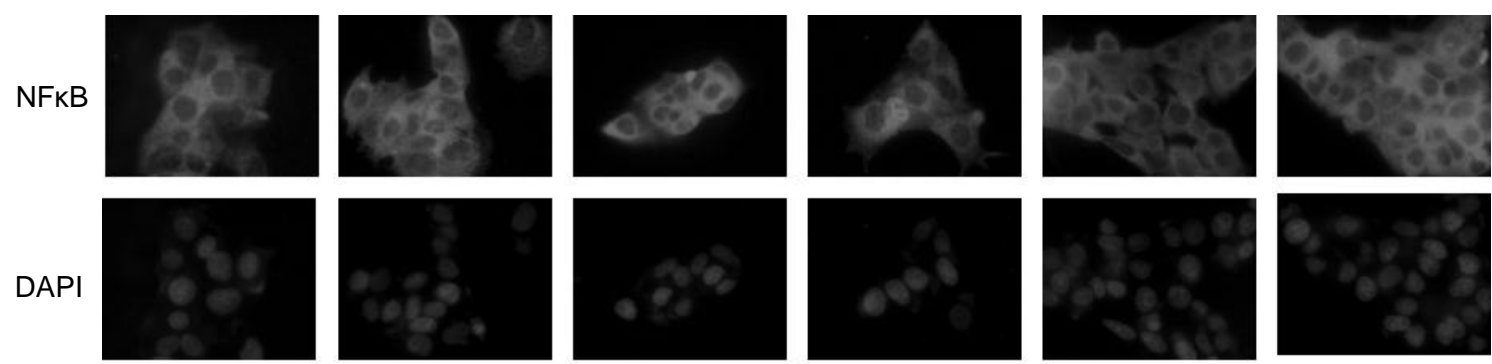

Q 0

0.1

0.5

1

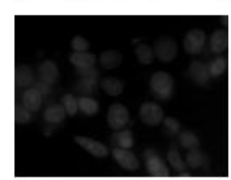

5

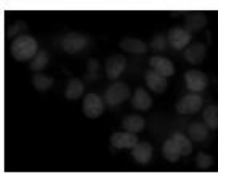

$10 \mu \mathrm{M}$ 
Figure 2

A

$\mathrm{NF} \kappa \mathrm{B}$

IKK

PARP

GRB2
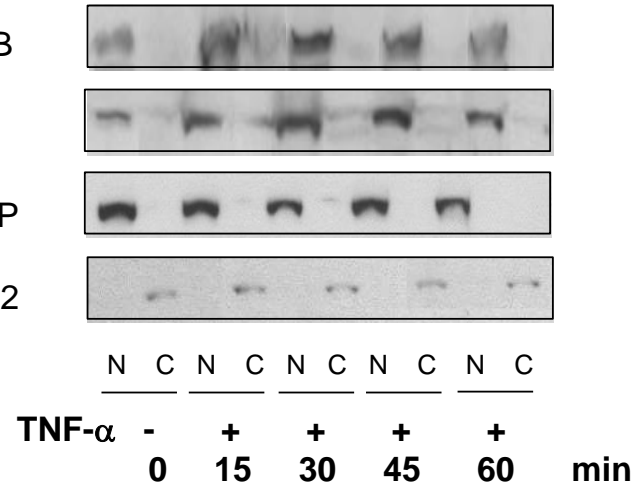

B
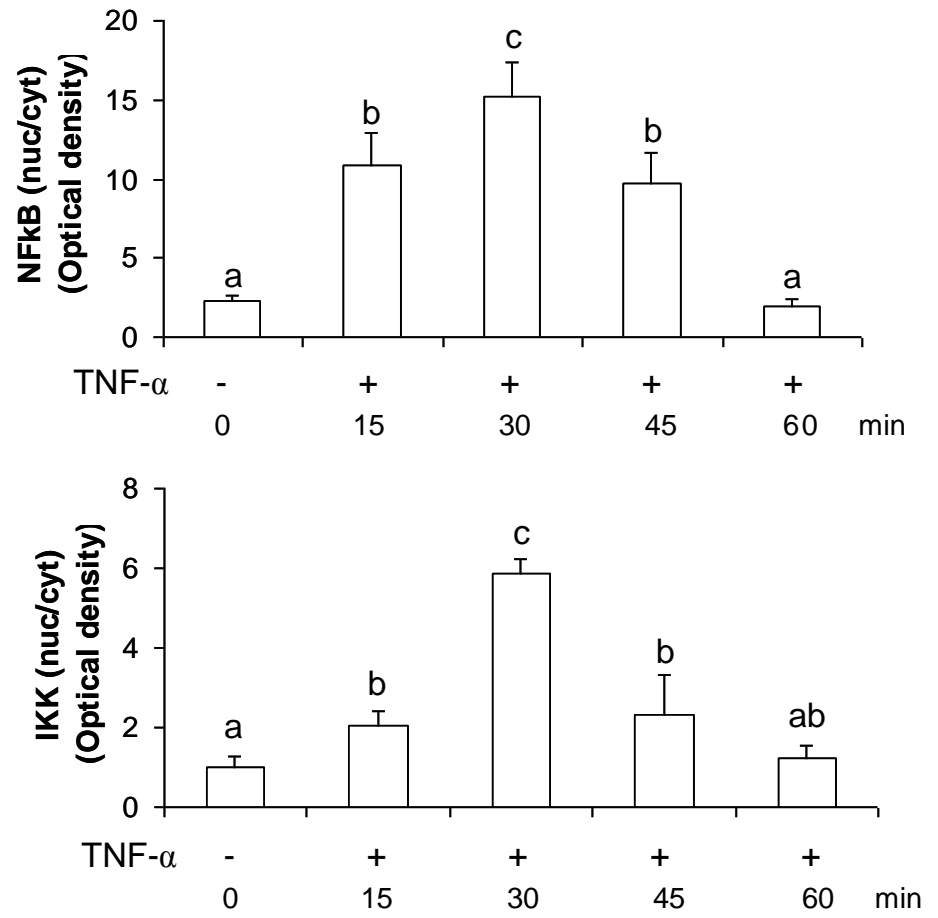

C
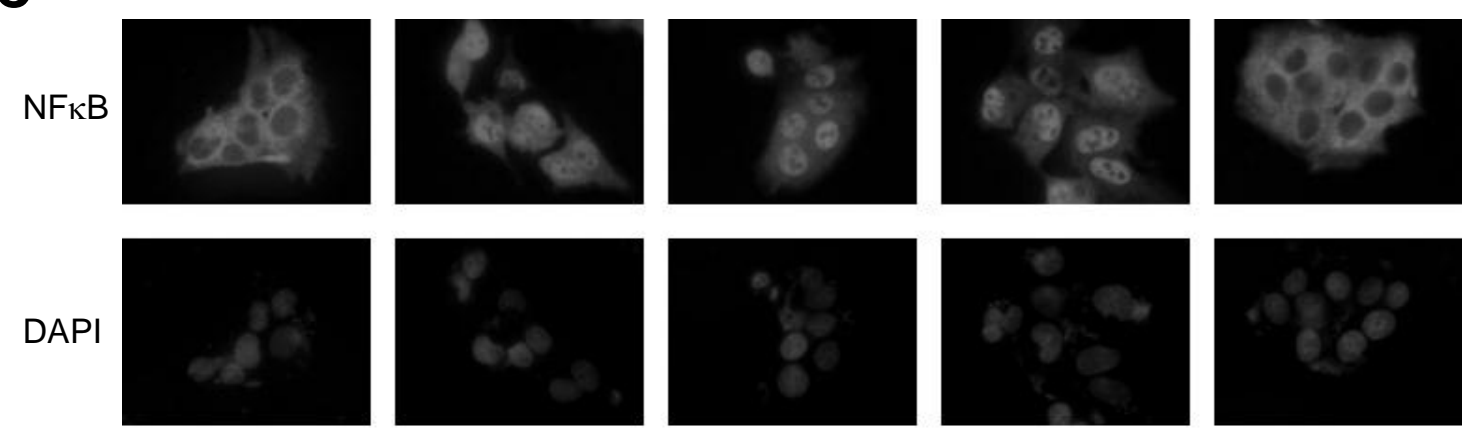

$\begin{array}{ll}\text { TNF- } \alpha & - \\ & 0\end{array}$

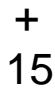

+
30

+
45

$+$

$60 \min$ 
Figure 3

A

$N F K B$

IKK

PARP

GRB2
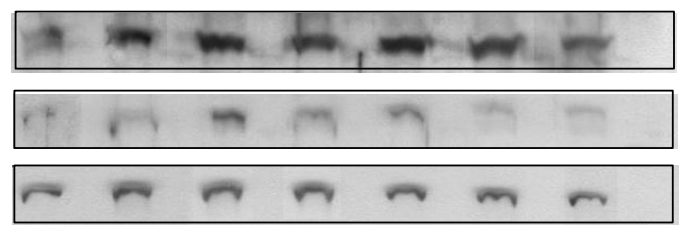

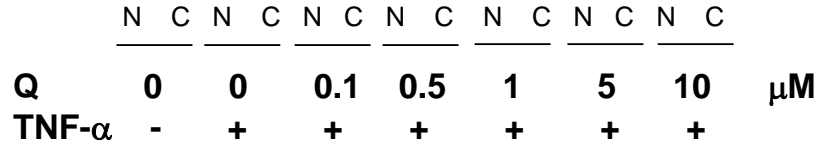

B
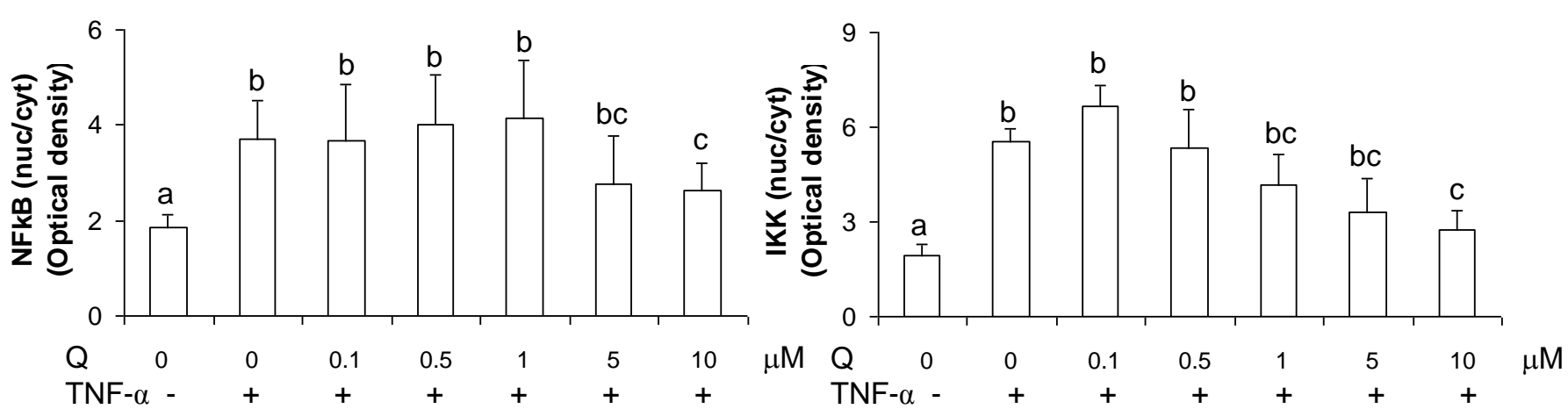

C

$\mathrm{NFkB}$
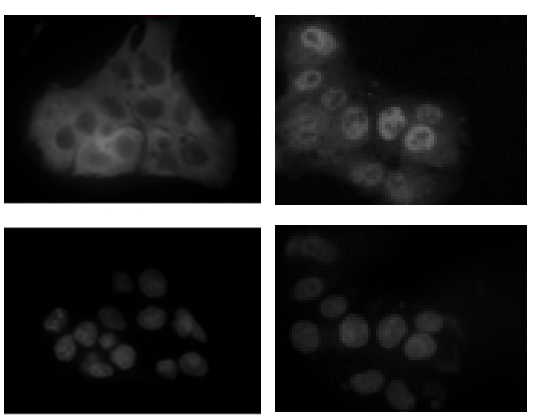

Q 0

TNF- $\alpha$ -
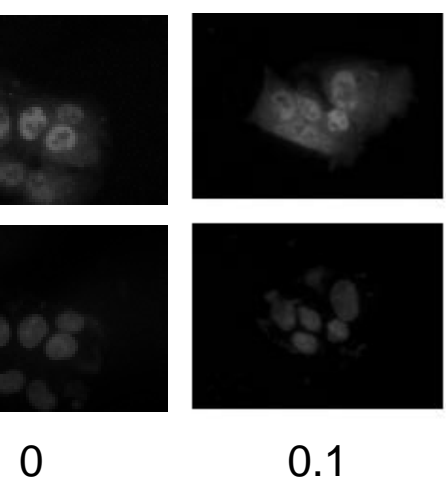

$+$

0.1

$+$
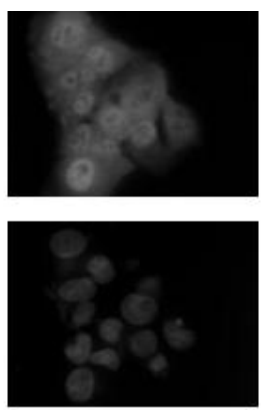

0.5
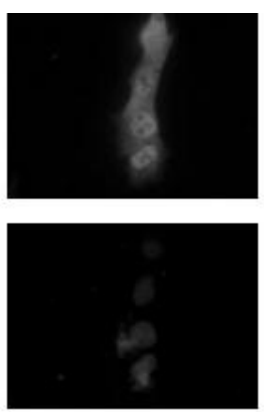
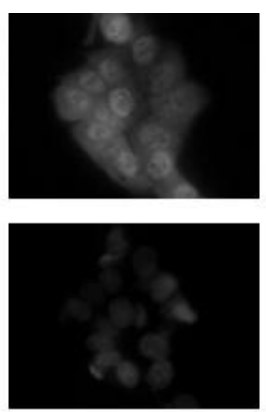

\section{5}
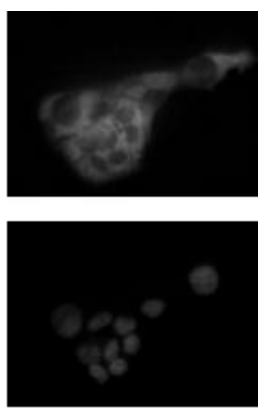

$10 \mu \mathrm{M}$

D

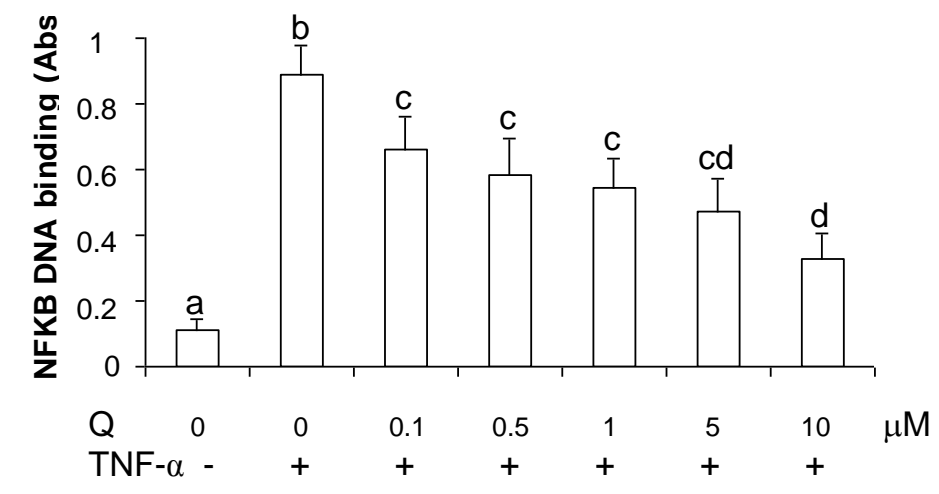


Figure 4

A

$\mathrm{p}-\mathrm{IKB}$

IKB

B-actin

$\begin{array}{rrrrrrr}\text { TNF- } \alpha & - & + & + & + & + & \\ & 0 & 15 & 30 & 45 & 60 & \min \end{array}$

B
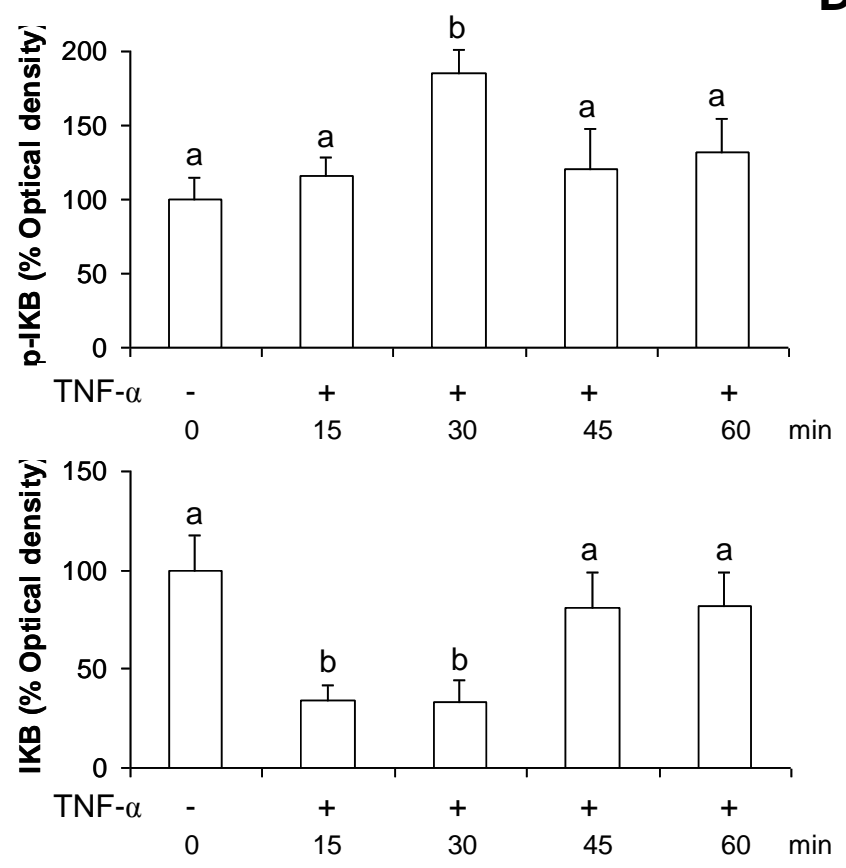

C

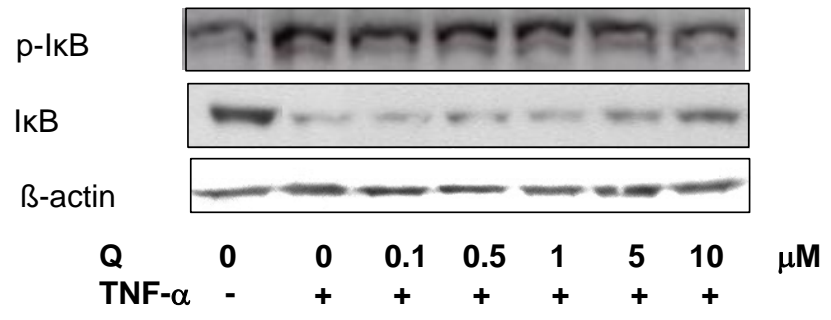

D
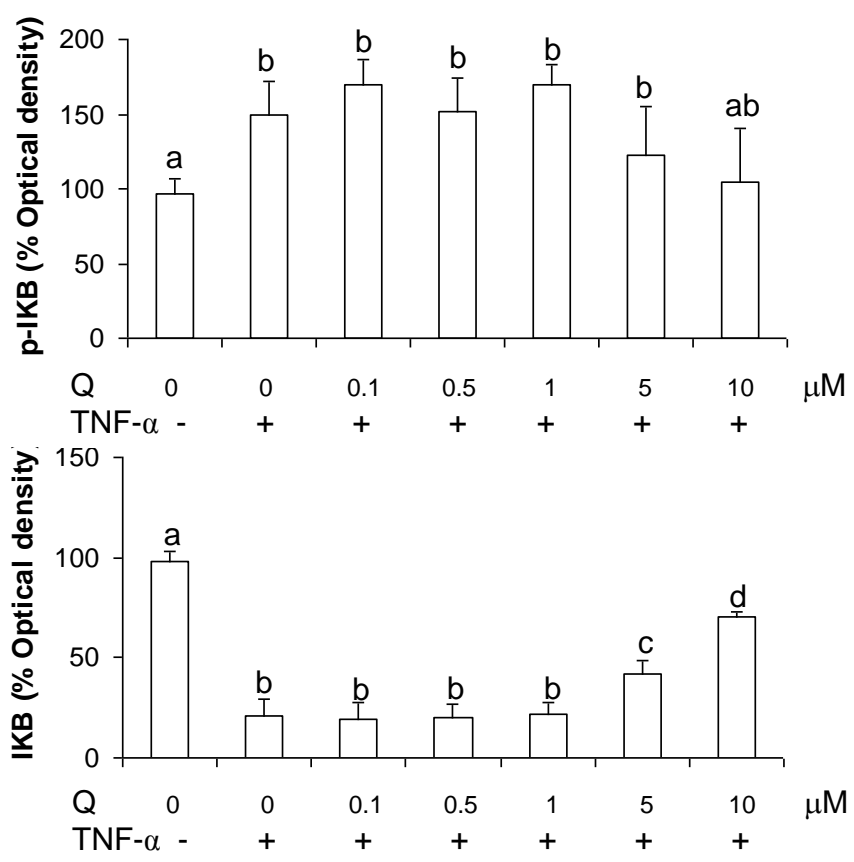
Figure 5

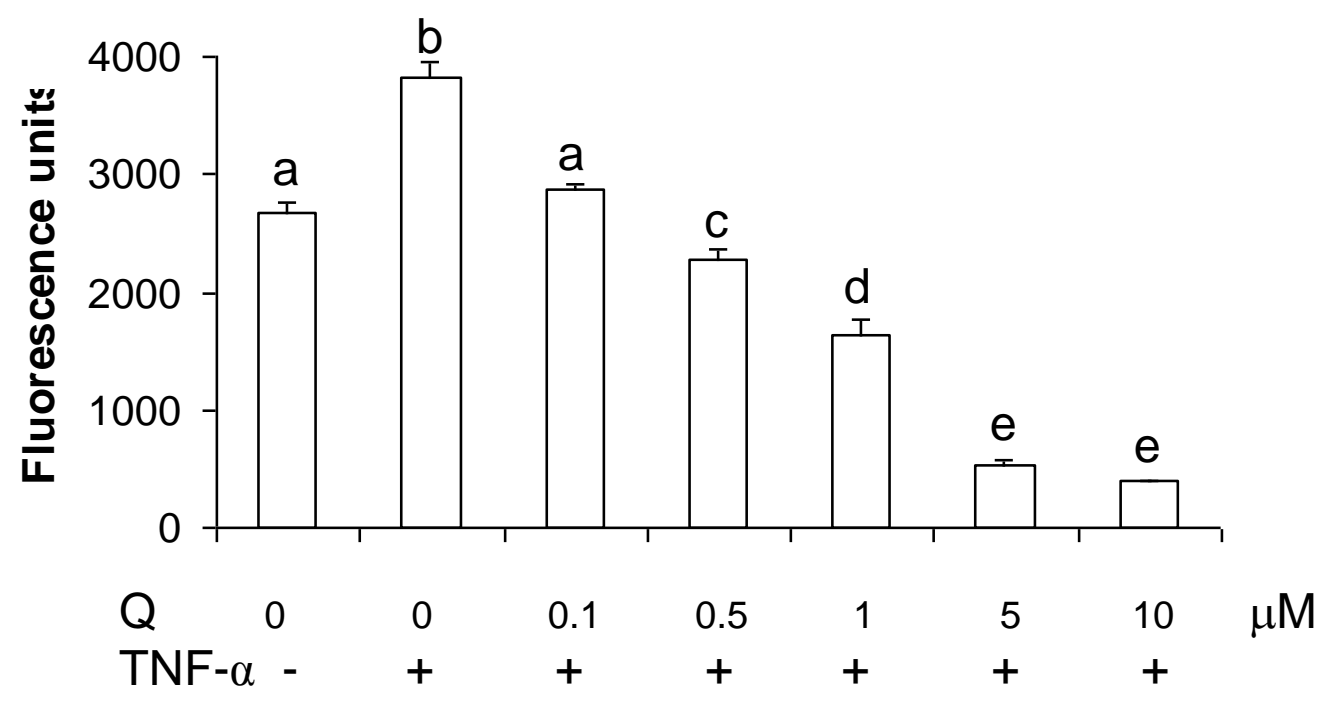


Figure 6

A

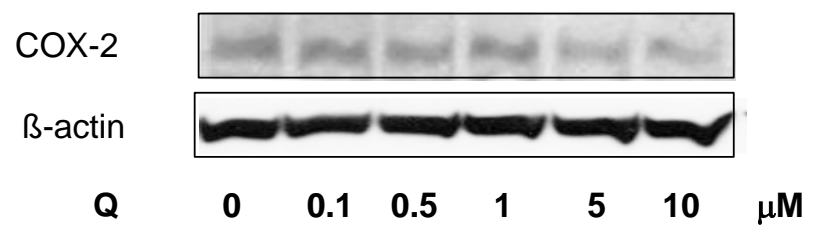

B

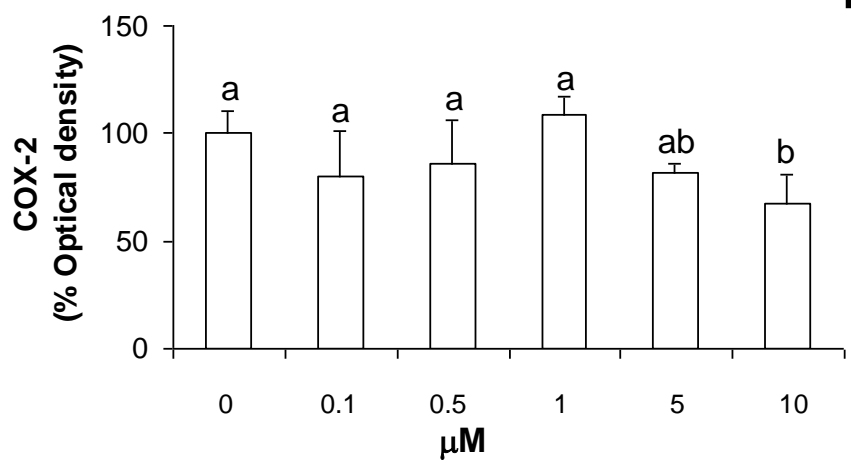

C

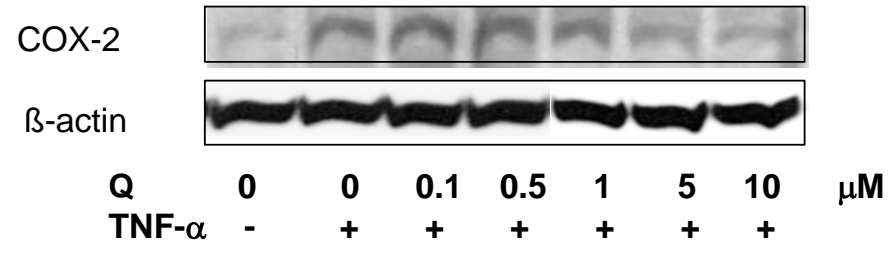

D

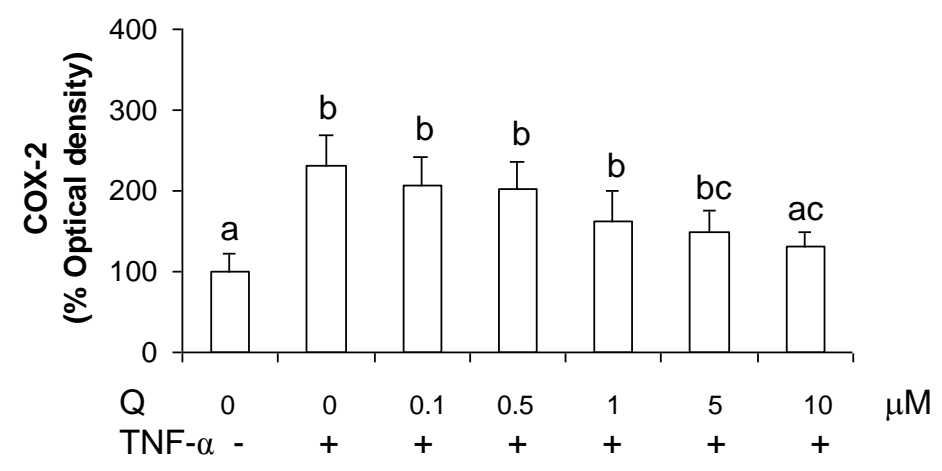


Figure 7

A

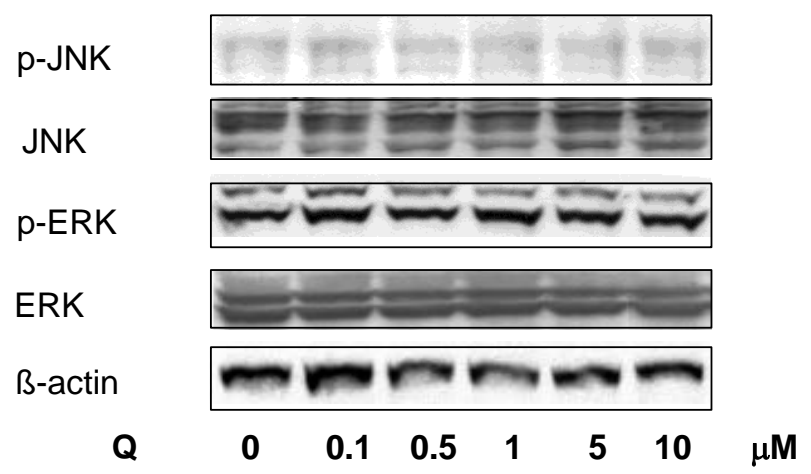

B
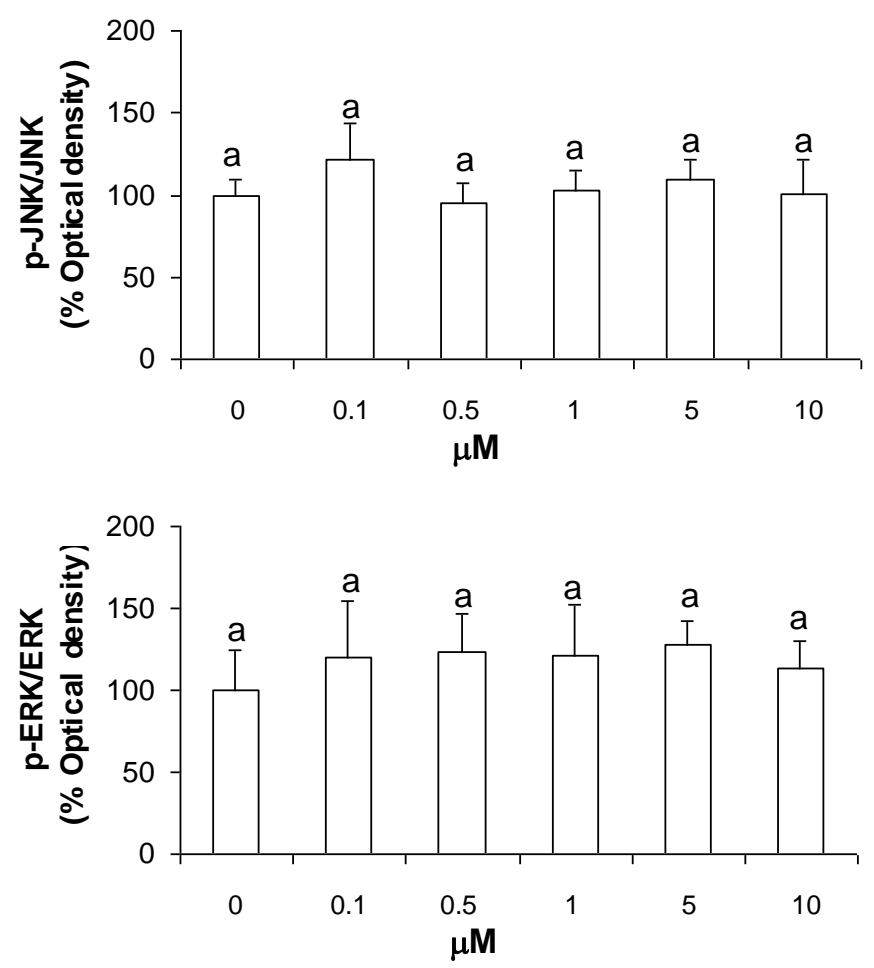

C

p-JNK

JNK

p-ERK

ERK

B-actin
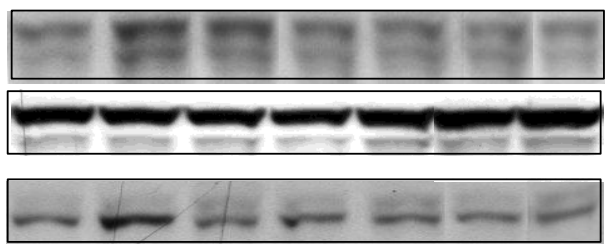

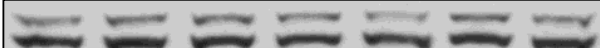

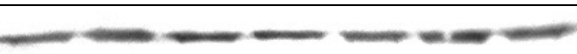

$\begin{array}{lllllllll}Q & 0 & 0 & 0.1 & 0.5 & 1 & 5 & 10 & \mu M\end{array}$

TNF- $\alpha$.

D
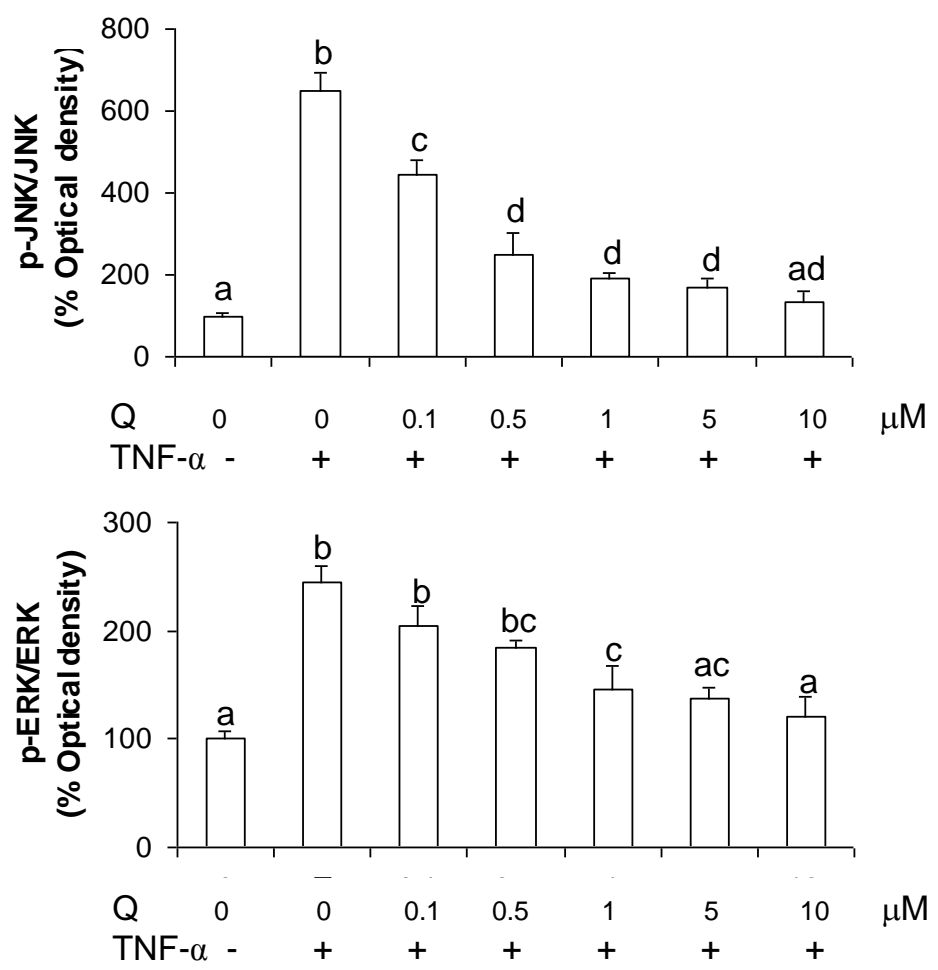
Table 1. Effect of quercetin on cell viability and proliferation after $24 \mathrm{~h}$ of treatment. Cell viability was determined either as relative percent of Crystal Violet stained control cells. Cell proliferation was calculated as percentage of the relative increase of BrdU incorporated into genomic DNA over the control values. Data represent the means $( \pm$ SD) of 8-10 separate experiments. Means within a column without a common letter differ, $\mathrm{P}<0.05$

\begin{tabular}{ccc}
\hline Quercetin & Cell viability & Cell proliferation \\
$\mu \mathrm{M}$ & $(\%$ of viable cells $)$ & $(\%$ of controls $)$ \\
\hline 0 & $100.16 \pm 2.05^{\mathrm{a}}$ & $100.27 \pm 6.85^{\mathrm{a}}$ \\
0.1 & $99.39 \pm 1.63^{\mathrm{a}}$ & $91.78 \pm 9.59^{\mathrm{a}}$ \\
0.5 & $98.45 \pm 1.17^{\mathrm{a}}$ & $93.47 \pm 7.86^{\mathrm{a}}$ \\
1 & $97.14 \pm 1.52^{\mathrm{a}}$ & $95.89 \pm 6.85^{\mathrm{a}}$ \\
5 & $97.18 \pm 1.57^{\mathrm{a}}$ & $91.78 \pm 8.22^{\mathrm{a}}$ \\
10 & $96.70 \pm 2.05^{\mathrm{a}}$ & $93.15 \pm 5.48^{\mathrm{a}}$ \\
\hline
\end{tabular}

